\title{
Dissolvable Microneedle Patches to Enable Increased Access to Vaccines against SARS-CoV-2 and Future Pandemic Outbreaks
}

\author{
Jesse O'Shea ${ }^{1, *}$, Mark R. Prausnitz ${ }^{2}$ (I) and Nadine Rouphael ${ }^{1}$ \\ 1 Hope Clinic of the Emory Vaccine Center, Division of Infectious Diseases, Department of Medicine, \\ School of Medicine, Emory University, 500 Irvin Court, Suite 200, Decatur, Atlanta, GA 30030, USA; \\ nroupha@emory.edu \\ 2 School of Chemical \& Biomolecular Engineering, Georgia Institute of Technology, Atlanta, GA 30332, USA; \\ prausnitz@gatech.edu \\ * Correspondence: jesse.oshea@emory.edu; Tel.: +1-404-712-1370
}

\section{check for}

updates

Citation: O'Shea, J.; Prausnitz, M.R.; Rouphael, N. Dissolvable

Microneedle Patches to Enable

Increased Access to Vaccines against SARS-CoV-2 and Future Pandemic Outbreaks. Vaccines 2021, 9, 320. https://doi.org/10.3390/vaccines 9040320

Academic Editors: Vita

Golubovskaya, Emmanuel Datan and Vasso Apostolopoulos

Received: 26 February 2021

Accepted: 30 March 2021

Published: 1 April 202

Publisher's Note: MDPI stays neutral with regard to jurisdictional claims in published maps and institutional affiliations.

Copyright: (c) 2021 by the authors. Licensee MDPI, Basel, Switzerland This article is an open access article distributed under the terms and conditions of the Creative Commons Attribution (CC BY) license (https:// creativecommons.org/licenses/by/ $4.0 /)$.

\begin{abstract}
Vaccines are an essential component of pandemic preparedness but can be limited due to challenges in production and logistical implementation. While vaccine candidates were rapidly developed against severe acute respiratory syndrome coronavirus 2 (SARS-COV-2), immunization campaigns remain an obstacle to achieving herd immunity. Dissolvable microneedle patches are advantageous for many possible reasons: improved immunogenicity; dose-sparing effects; expected low manufacturing cost; elimination of sharps; reduction of vaccine wastage; no need for reconstitution; simplified supply chain, with reduction of cold chain supply through increased thermostability; ease of use, reducing the need for healthcare providers; and greater acceptability compared to traditional hypodermic injections. When applied to coronavirus disease 2019 (COVID-19) and future pandemic outbreaks, microneedle patches have great potential to improve vaccination globally and save many lives.
\end{abstract}

Keywords: dissolvable microneedle patch; drug delivery; skin vaccination; vaccine delivery; equity

\section{Introduction}

Many of the great pandemics in the 20th and 21st centuries have been caused either by an influenza or coronavirus. Many experts have warned that repeated pandemics are inevitable and likely imminent [1]. Vaccines are an essential component of pandemic preparedness but can be limited due to challenges in production and logistical implementation. Now, in one year, the coronavirus disease 2019 (COVID-19) pandemic, caused by severe acute respiratory syndrome coronavirus 2 (SARS-CoV-2), has led to 100 million confirmed infections and more than 2 million deaths worldwide [2].

The COVID-19 pandemic has overwhelmed both health and economic systems. While vaccine candidates were rapidly developed against SARS-COV-2, immunization campaigns remain an obstacle to achieving herd immunity. In previous pandemics, some countries have had trouble accessing vaccines and other essential health products [3]. Overwhelming demand, scarce manufacturing capacity, high costs, dependency on cold chain supply, and lack of global allocation mechanisms have played a role in those delays [3]. Most vaccines for SARS-CoV-2 are injected using a hypodermic needle and require multiple doses. For example, authorized vaccines including mRNA-based technology, such as Moderna's mRNA-1273, Pfizer/BioNTech's Comirnaty, and other vaccines like Oxford/AstraZeneca's AZD1222, Johnson \& Johnson's Ad26.COV2.S, Sinovac's CoronaVac, Sinopharm's BBIBPCorV, CanSinoBIO's Convidecia, Gamaleya's Sputnik V, BEKTOP's EpiVacCorona, and Bharat Biotech's Covaxin, mostly require two doses administered by specially trained healthcare providers and have cold chain distribution requirements ranging from $-70{ }^{\circ} \mathrm{C}$ to $8{ }^{\circ} \mathrm{C}$, which presents significant logistical limitations [4-7]. 
Given these challenges, in addition to regional protectionism, the implementation of vaccination programs could be jeopardized. The founding of the COVID-19 Vaccines Global Access (COVAX) Facility by Gavi, the Coalition for Epidemic Preparedness Innovations (CEPI), and the World Health Organization (WHO) is an attempt to garner resources and unite higher- and lower-income countries for a coordinated, rapid, transparent, and equitable access to COVID-19 vaccines worldwide.

The WHO identified vaccine hesitancy as one of the top ten global health threats in 2019 [8]. Vaccine hesitancy is further magnified by needle-phobia, pain, fear of complications, and fear of leaving quarantine to a healthcare setting [9]. National surveys during the COVID-19 pandemic report that roughly $30 \%$ of adults are not sure whether they would be vaccinated and $10 \%$ did not intend to be vaccinated $[9,10]$. The spread of bloodborne pathogens by needle re-use is also a major concern, along with a shortage of healthcare providers, especially in developing countries. New and innovative vaccine technology and delivery mechanisms may assist in addressing these challenges.

As a possible solution for pandemic countermeasures, dissolvable microneedle patches should be considered as a vaccine delivery method (Figure 1). The patches consist of micronscale solid conical structures made of dissolvable excipients on a skin patch backing that deliver vaccine antigens across the stratum corneum barrier into the viable epidermis and dermis of the skin. As microneedles are less than one millimeter long, they cause little or no pain and are strongly preferred over traditional immunization by injection [11]. Further, microneedle patches require no special training to be administered, do not generate biohazardous sharps waste, and can be formulated for thermostability [11].

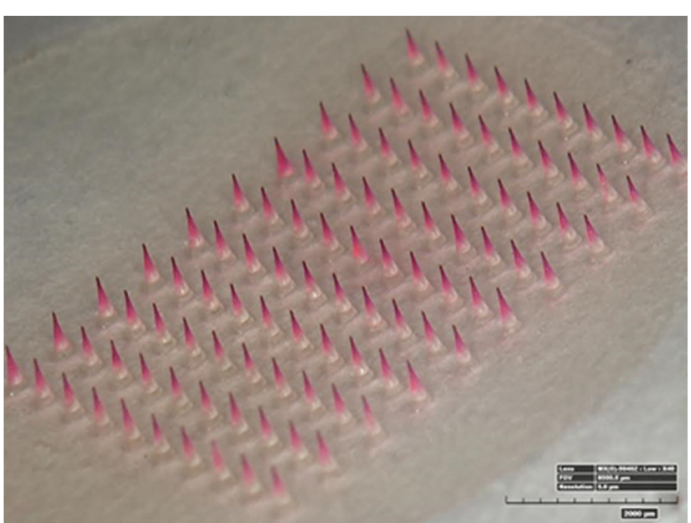

(a)

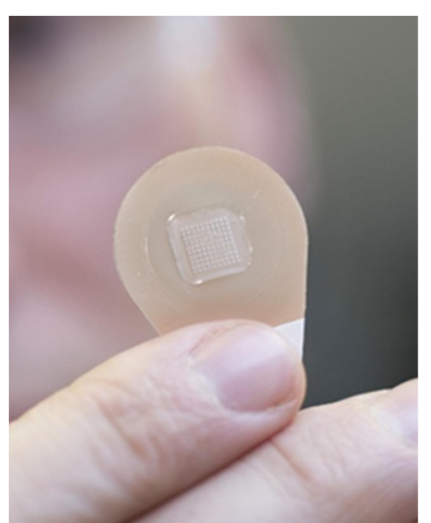

(b)

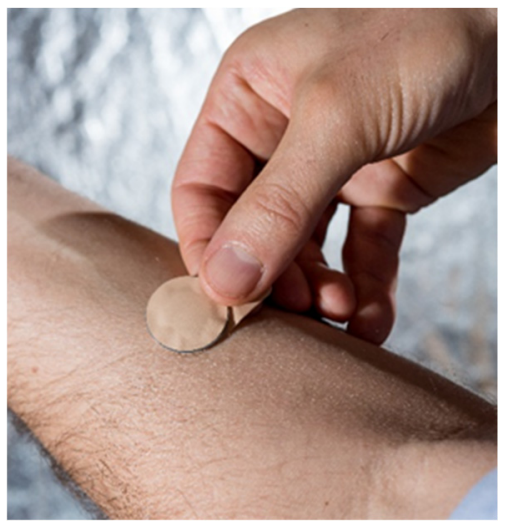

(c)

Figure 1. Dissolvable microneedle patch for simplified vaccination. (a) An array of microneedles containing pink dye to simulate vaccine. A microneedle patch (b) showing the microneedle array, adhesive backing, and non-adhesive tab for handling. (c) A microneedle patch being applied to the skin. Images courtesy of (a) Devin McAllister, Georgia Tech, (b) Christopher Moore, Georgia Tech, and (c) Rob Felt, Georgia Tech. 
This paper examines the potential ways that microneedle patches may overcome limitations in traditional vaccination campaigns by hypodermic injection and review their applications to the current COVID-19 pandemic and beyond.

\section{Discussion}

\subsection{Overcoming Barriers to Effective Vaccination}

There are several barriers for effective vaccination campaigns in all resource settings, including the need to increase vaccine immune response, simplify the supply chain, eliminate biohazardous waste, improve cost-effectiveness, and reduce reliance on trained healthcare providers [12].

Microneedle patches have been studied for their potential application against many pathogens, including other respiratory viruses (see Table 1). For seasonal influenza, vaccination by microneedle patches resulted in faster virus clearance in the lungs of murine models [13]. For pandemic influenza, higher immunogenicity was noted in animal models compared to intramuscular injection [14]. Delivering vaccines in the epidermis or dermis puts the antigen in close contact with the skin's rich population of antigen-presenting cells and can result in lower doses of antigens being used. Vaccinations using microneedle patches have demonstrated dose-sparing in clinical studies [15]. The use of microneedle devices ensures a more accurate, effective, and reproducible delivery of vaccine to the skin compared to injections [11]. Our clinic recently conducted a first-in-human clinical trial where outcomes after inactivated influenza vaccination by intramuscular injection were compared to dissolvable microneedle patch, which revealed similar antibody response robustness and better acceptance $[16,17]$.

Table 1. Vaccines studied using dissolvable microneedle patches.

\begin{tabular}{|c|c|c|c|}
\hline Nucleic Acid & $\begin{array}{l}\text { Protein-Based (Including } \\
\text { Virus-Like Particle (VLP)) }\end{array}$ & Inactivated/Live Attenuated & Viral Vector \\
\hline Ebola [18] & Diphtheria [19-21] & Adenovirus [22-24] & \multirow{12}{*}{$\begin{array}{c}\text { HIV [25-27] } \\
\text { Middle East Respiratory } \\
\text { Syndrome } \\
\text { (MERS-CoV-S1) [34] } \\
\text { Zika [41] }\end{array}$} \\
\hline Hepatitis B virus [28] & $\begin{array}{l}\text { EV71 hand-foot-and-mouth } \\
\text { disease (HFMD) [29] }\end{array}$ & Influenza [16,30-33] & \\
\hline Porcine circovirus type 2 [35] & Hepatitis B [36-38] & Measles $[39,40]$ & \\
\hline Rabies [42] & $\begin{array}{l}\text { Human immunodeficiency virus } \\
\text { (HIV) [43] }\end{array}$ & $\begin{array}{l}\text { Modified vaccinia virus } \\
\quad \text { Ankara (MVA) [22] }\end{array}$ & \\
\hline \multirow[t]{8}{*}{$\begin{array}{l}\text { Tuberculosis bacillus } \\
\text { Calmette-Guérin (BCG) [44] }\end{array}$} & $\begin{array}{c}\text { Human papillomavirus infection } \\
\text { (HPV) }[45,46]\end{array}$ & Neisseria gonorrhoeae [47] & \\
\hline & Herpes simplex virus 2 [48] & Poliovirus [49-51] & \\
\hline & Influenza $[19,22,52-64]$ & Pseudomonas aeruginosa [65] & \\
\hline & Leishmania [66] & Rotavirus [67] & \\
\hline & Malaria [19] & Rubella [39] & \\
\hline & SARS-2-CoV $[34,68]$ & Streptococcus [69] & \\
\hline & Staphylococcal [70] & $\begin{array}{c}\text { Tuberculosis bacillus } \\
\text { Calmette-Guérin (BCG) [71] }\end{array}$ & \\
\hline & $\begin{array}{c}\text { Scrub typhus [72] } \\
\text { Tetanus (toxoid) }[20,73,74] \\
\text { Mycobacterium tuberculosis [75] } \\
\text { Zika [41] }\end{array}$ & & \\
\hline
\end{tabular}

A large healthcare workforce is required to have mass vaccination campaigns, which can be limited in developing countries and could cause crowding in the pandemic era. Most vaccines that are administered by hypodermic needle and syringe injection require a trained healthcare provider to administer the vaccine. Microneedle patch vaccination allows for administration by minimally trained personnel, including self-administration, which could dramatically hasten roll-out and dissemination as well as reduce the burden on the healthcare system. Acceptability studies using pressure sensitive microneedle patches with an auditory force feedback indicator found that participants reported little to no 
pain with self-administration and overwhelmingly preferred microneedle patches over intramuscular injections [76].

Microneedle patches reduce the risk of sharps and sharps waste because the microneedles disappear after dissolving in the skin. The risks with sharps include unintentional re-use, needlestick injuries, and cross contamination. Up to 3.62 per 100,000 vaccinations result in needle-stick injury. The spread of bloodborne pathogens is a major concern, with an estimated 1.3 million deaths resulting from needle re-use according to WHO estimates, especially in developing countries $[77,78]$. Further, dissolvable microneedle patches are a safe delivery method, with no reports to date of accidental infection in controlled studies and widespread use in commercial cosmetic products [79-81].

Standard hypodermic needle vaccination may be wasteful via multi-dose vials and the need for reconstitution. In general, vaccine wastage rates increase as the number of vaccine doses per vial increases. Estimates suggest wastage rates for 10-dose vials may be as high as $25 \%$ for liquid vaccines and $40 \%$ for lyophilized vaccines [15,82]. Single-use microneedle patches remove this waste seen in multi-dose vials. Some vaccines need vaccine reconstitution with a diluent, which not only requires a trained healthcare provider to perform but also adds more needles, syringes, and vials that need to be safely stored and transported [15]. Microneedle patches do not require reconstitution.

Microneedle patches have improved stability and can often be stored at ambient temperature, eliminating the cold chain, and allowing for easier stockpile and storage $[15,82]$. Further, the patches are much smaller in size than vaccine vial and needle-syringe systems, facilitating storage and distribution, and thereby simplifying the supply chain.

The cost of vaccination is the cost of vaccine plus the logistical costs associated with making the vaccine available for use. Healthcare providers, waste disposal, vaccine storage, transportation, cold chain, and vaccine wastage all contribute to the cost of vaccination. While vaccine manufacturers often sell vaccines at significantly reduced cost for use in developing countries, the logistical costs to vaccinate can remain a significant barrier. Analyses suggest that the use of self-administered microneedle patches could not only improve vaccination coverage but would also be cost-effective $[83,84]$. The cost of microneedle patch manufacturing is expected to be lower than pre-filled syringes because the materials are generally low-cost medical-grade polymers and other excipients used in very small amounts. A representative microneedle array weighs less than $1 \mathrm{~g}$, and the backing, adhesive, and packaging are usually made of conventional pharmaceutical supplies used in transdermal patches and other medical products [15].

Limitations of dissolving microneedle patch delivery systems for vaccines exist, including theoretical issues with dosage accuracy; inability to deliver large doses of medications (which could be an issue if using certain adjuvants require milligram doses); possibility of skin irritation and external environment affecting delivery, such as hydration of the skin or excessive sweating; and uncertainty about cost and capability of large-scale manufacturing [13]. These limitations have not presented significant issues in human clinical trials or other studies to date.

\subsection{COVID-19 Microneedle Applications}

The science of microneedle patches is robust, as shown by the many different licensed and experimental vaccines delivered (see Table 1). Four weeks after the identification of the SARS-CoV-2 S1 sequence, Kim et al. designed carboxymethyl cellulose-based dissolvable microneedle patches containing Middle East Respiratory Syndrome Coronavirus subunit MERS-CoV-S1 and SARS-CoV-2 vaccines capable of generating potent antigen-specific IgG responses [68]. The MERS-CoV-S1 vaccines induced stronger humoral responses than traditional needle injections and resulted in stronger IgG responses than via subcutaneous injection [68]. For MERS-CoV-S1, which started prior to the SARS-CoV-2 portion of the study, antibody levels continued to increase over time in mice vaccinated by microneedle patch - up to when the experiment ended at 55 weeks [68]. In another study, Kuwentrai et al. successfully designed and used dissolving microneedle patches based on a mixture of 
the receptor-binding domain (RBD) spike proteins and low-molecular weight hyaluronic acid (HA) together with an aluminum hydroxide gel adjuvant using a micro-molding method [34]. The team found specific B-cell antibodies and IFN- $\gamma$ T-cell responses for up to 97 days after administration, though with high variation of antibody titers compared to subcutaneous injection [34]. The potential advantages of dissolvable microneedle patches for COVID-19 can be found in Table 2.

Table 2. Potential advantages of dissolvable microneedle patch vaccine for coronavirus disease 2019 (COVID-19).

\begin{tabular}{c}
\hline Increased Immunogenicity \\
Faster virus clearance \\
Dose-sparing effect \\
Reduction in vaccination wastage \\
Avoidance of reconstitution \\
Increased acceptance and less hesitancy \\
Little or no pain \\
Self-administration and reduced need for healthcare workforce \\
Reduced risk of sharps injury and contamination \\
Improved stability \\
Less reliance on cold chain
\end{tabular}

Recently, the US government through the Biomedical Advanced Research and Development Authority (BARDA) funded a total of $\$ 1.9$ million to three groups developing microneedle skin patches [85]. The patches will contain the SARS-CoV-2 spike protein-the basis of nearly all COVID-19 vaccines. The patches are intended to be shelf-stable, selfadministered, and self-boosting by releasing the spike protein into the body as pulses or continuously over a few weeks. This approach could eliminate the need for repeated vaccinations. Several universities and companies have announced that they are initiating pre-clinical studies for a SARS-CoV-2 vaccination using microneedle patches, but no data are available yet.

In response to the COVID-19 outbreak, there was an unprecedented effort to develop new vaccines with remarkable speed. The current bottleneck, however, is the rapid distribution and administration of the vaccines to achieve herd immunity in the global population. This depends not only on manufacturing sufficient vaccine supply, but also on the logistical and fiscal challenges of global distribution, sometimes complex cold chain requirements, and the need for skilled human capital.

Microneedle patch vaccination can ease these limitations of traditional vaccination methods, especially in resource-limited settings, although the slow pace of vaccination even in advanced economies points to the need for simplified vaccination mechanisms worldwide. However, microneedle patches for SARS-CoV-2 vaccination are currently not available due in large part to a lack of existing manufacturing and regulatory infrastructure needed for rapid development. Continued and expanded investment in innovative vaccine delivery platforms such as microneedle patches is needed to ensure the technology and infrastructure are in place for the pandemic needs of the future.

\section{Conclusions}

Microneedle patch immunization has the potential to overcome many factors affecting the uptake and distribution of traditional hypodermic intramuscular injection campaigns. Dissolvable microneedle patches are advantageous for many possible reasons: improved immunogenicity; dose-sparing effects; expected low manufacturing cost; elimination of sharps; reduction of vaccine wastage; no need for reconstitution; simplified supply chain, with reduction of cold chain supply through increased thermostability; ease of use, reducing the need for healthcare providers; and greater acceptability compared to traditional hypodermic injections. When applied to COVID-19, microneedle patches have great potential to improve vaccination globally and save many lives. While the timeline for 
COVID-19 microneedle patch vaccine deployment may be a missed opportunity for the current pandemic, there is a need for investment today to be better prepared for tomorrow's pandemic needs.

Author Contributions: J.O., M.R.P. and N.R. conceived the viewpoint, designed the review, acquired data, and performed data analysis. J.O. drafted the manuscript; all authors contributed to the interpretation of results and manuscript revision. All authors have read and agreed to the published version of the manuscript.

Funding: This research received no external funding. The funding source had no role in study methods, conclusion, or the decision to publish. The corresponding author had full access to all the data in the study and the final responsibility for the decision to submit for publication.

Conflicts of Interest: M.R.P. is an inventor of patents licensed to companies developing microneedlebased products, is a paid advisor to companies developing microneedle-based products, and is a founder/shareholder of companies developing microneedle-based products (Micron Biomedical). This potential conflict of interest has been disclosed and is managed by Georgia Institute of Technology. N.R. receives institutional funds from Merck, Sanofi Pasteur, Lilly, Quidel, and Pfizer. All other authors have nothing to disclose. The funders had no role in the design of the study; in the collection, analyses, or interpretation of data; in the writing of the manuscript, or in the decision to publish the results.

\section{References}

1. Webby, R.J.; Webster, R.G. Are we ready for pandemic influenza? Science 2003, 302, 1519-1522. [CrossRef] [PubMed]

2. Dong, E.; Du, H.; Gardner, L. An interactive web-based dashboard to track COVID-19 in real time. Lancet Infect. Dis. 2020, 20, 533-534. [CrossRef]

3. World Health Organization. WHO Concept for Fair Access and Equitable Allocation of COVID-19 Health Prod-ucts; WHO: Geneva, Switzerland, 2020. Available online: https://www.who.int/publications/m/item/fair-allocation-mechanism-for-covid-19 -vaccines-through-the-covax-facility (accessed on 29 January 2021).

4. Rose, A.; Triano, C.; Alatovic, J.; Maas, S. "Pfizer and Biontech Conclude Phase 3 Study of Covid-19 Vaccine Candidate." Meeting All Primary Efficacy Endpoints. Available online: https://www.pfizer.com/news/press-release/press-release-detail/pfizer-andbiontech-conclude-phase-3-study-covid-19-vaccine (accessed on 29 January 2021).

5. Moderna Therapeutics. Moderna's COVID-19 Vaccine Candidate Meets its Primary Efficacy Endpoint in the First Interim Analysis of the Phase 3 COVE Study. Moderna. Available online: https://investors.modernatx.com/news-releases/news-releasedetails / moderna-announces-longer-shelf-life-its-covid-19-vaccine (accessed on 29 January 2021).

6. Voysey, M.; Clemens, S.A.; Madhi, S.A.; Weckx, L.Y.; Folegatti, P.M.; Aley, P.K.; Angus, B.; Baillie, V.L.; Barnabas, S.L.; Bhorat, Q.E.; et al. Safety and efficacy of the ChAdOx1 nCoV-19 vaccine (AZD1222) against SARS-CoV-2: An interim analysis of four randomised controlled trials in Brazil, South Africa, and the UK. Lancet 2021, 397, 99-111. [CrossRef]

7. Corum, J.; Wee, S.; Zimmer, C. Coronavirus Vaccine Tracker. 2020. Available online: https://www.nytimes.com/interactive/2020 / science/coronavirus-vaccine-tracker.html (accessed on 29 January 2021).

8. World Health Organization. Ten Threats to Global Health in 2019. Available online: https://www.who.int/news-room/spotlight/ ten-threats-to-global-health-in-2019 (accessed on 29 January 2021).

9. Fisher, K.A.; Bloomstone, S.J.; Walder, J.; Crawford, S.; Fouayzi, H.; Mazor, K.M. Attitudes toward a potential SARS-CoV-2 vac-cine: A survey of US adults. Ann. Intern. Med. 2020, 173, 964-973. [CrossRef] [PubMed]

10. Lazarus, J.V.; Ratzan, S.C.; Palayew, A.; Gostin, L.O.; Larson, H.J.; Rabin, K.; Kimball, S.; El-Mohandes, A. A global survey of po-tential acceptance of a COVID-19 vaccine. Nat. Med. 2020, 27, 225-228. [CrossRef]

11. Prausnitz, M.R.; Mikszta, J.A.; Cormier, M.; Andrianov, A.K. Microneedle-based vaccines. Curr. Top. Microbiol. Immunol. 2009, $333,369-393$.

12. Rodgers, A.M.; Cordeiro, A.S.; Donnelly, R.F. Technology update: Dissolvable microneedle patches for vaccine delivery. Med. Devices Évid. Res. 2019, 12, 379-398. [CrossRef] [PubMed]

13. Sullivan, S.P.; Koutsonanos, D.G.; Martin, M.D.P.; Lee, J.W.; Zarnitsyn, V.; Choi, S.-O.; Murthy, N.; Compans, R.W.; Skountzou, I.; Prausnitz, M.R. Dissolving polymer microneedle patches for influenza vaccination. Nat. Med. 2010, 16, 915-920. [CrossRef]

14. Kim, Y.C.; Song, J.M.; Lipatov, A.S.; Choi, S.O.; Lee, J.W.; Donis, R.O.; Compans, R.W.; Kang, S.M.; Prausnitz, M.R. Increased immuno-genicity of avian influenza DNA vaccine delivered to the skin using a microneedle patch. Eur. J. Phar-Maceutics Biopharm. 2012, 81, 239-247. [CrossRef]

15. Arya, J.; Prausnitz, M.R. Microneedle patches for vaccination in developing countries. J. Control. Release 2016, $240,135-141$. [CrossRef]

16. Rouphael, N.G.; Paine, M.; Mosley, R.; Henry, S.; McAllister, D.V.; Kalluri, H.; Pewin, W.; Frew, P.M.; Yu, T.; Thornburg, N.J.; et al. The safety, immunogenicity, and acceptability of inactivated influenza vaccine delivered by microneedle patch (TIV-MNP 2015): A randomised, partly blinded, placebo-controlled, phase 1 trial. Lancet 2017, 390, 649-658. [CrossRef] 
17. Frew, P.M.; Paine, M.B.; Rouphael, N.; Schamel, J.; Chung, Y.; Mulligan, M.J.; Prausnitz, M.R. Acceptability of an inactivated influenza vaccine delivered by microneedle patch: Results from a phase I clinical trial of safety, reactogenicity, and im-munogenicity. Vaccine 2020, 38, 7175-7181. [CrossRef]

18. Yang, H.-W.; Ye, L.; Guo, X.D.; Yang, C.; Compans, R.W.; Prausnitz, M.R. Ebola Vaccination Using a DNA Vaccine Coated on PLGA-PLL $/ \gamma$ PGA Nanoparticles Administered Using a Microneedle Patch. Adv. Healthc. Mater. 2017, 6. [CrossRef]

19. Matsuo, K.; Hirobe, S.; Yokota, Y.; Ayabe, Y.; Seto, M.; Quan, Y.S.; Kamiyama, F.; Tougan, T.; Horii, T.; Mukai, Y.; et al. Transcutaneous immunization using a dissolving microneedle array protects against tetanus, diphtheria, malaria, and influenza. J. Control. Release 2012, 160, 495-501. [CrossRef]

20. Hiraishi, Y.; Nakagawa, T.; Quan, Y.-S.; Kamiyama, F.; Hirobe, S.; Okada, N.; Nakagawa, S. Performance and characteristics evaluation of a sodium hyaluronate-based microneedle patch for a transcutaneous drug delivery system. Int. J. Pharm. 2013, 441, 570-579. [CrossRef] [PubMed]

21. Leone, M.; Romeijn, S.; Du, G.; Dévédec, S.E.; Vrieling, H.; O’Mahony, C.; Bouwstra, J.A.; Kersten, G. Diphtheria toxoid dis-solving microneedle vaccination: Adjuvant screening and effect of repeated-fractional dose administration. Int. J. Pharm. 2020, 580, 119182. [CrossRef] [PubMed]

22. Vrdoljak, A.; Allen, E.A.; Ferrara, F.; Temperton, N.J.; Crean, A.M.; Moore, A.C. Induction of broad immunity by thermostabi-lised vaccines incorporated in dissolvable microneedles using novel fabrication methods. J. Control. Release 2016, 225, 192-204. [CrossRef] [PubMed]

23. Erdos, G.; Donahue, C.; Zhang, J.; Ozdoganlar, B.; Gambotto, A.; Falo, L. Dissolvable microneedle arrays deliver live adeno-virus to the skin for genetic immunization. J. Immunol. 2012, 188, 58.

24. Erdos, G.; Balmert, S.C.; Carey, C.D.; Falo, G.D.; Patel, N.A.; Zhang, J.; Gambotto, A.; Korkmaz, E.; Falo, L.D. Improved cutaneous genetic immunization by microneedle array delivery of an adjuvanted adenovirus vaccine. J. Investig. Dermatol. 2020, 140, 2528-2531.e2. [CrossRef]

25. Bachy, V.; Hervouet, C.; Becker, P.D.; Chorro, L.; Carlin, L.M.; Herath, S.; Papagatsias, T.; Barbaroux, J.B.; Oh, S.J.; Benlahrech, A.; et al. Langerin negative dendritic cells promote potent CD8+ T-cell priming by skin delivery of live ad-enovirus vaccine microneedle arrays. Proc. Natl. Acad. Sci. USA 2013, 110, 3041-3046. [CrossRef]

26. Becker, P.D.; Hervouet, C.; Mason, G.M.; Kwon, S.-Y.; Klavinskis, L.S. Skin vaccination with live virus vectored microneedle arrays induce long lived CD8+ T cell memory. Vaccine 2015, 33, 4691-4698. [CrossRef]

27. Zaric, M.; Becker, P.D.; Hervouet, C.; Kalcheva, P.; Yus, B.I.; Cocita, C.; O’Neill, L.A.; Kwon, S.Y.; Klavinskis, L.S. Long-lived tissue resident HIV-1 specific memory CD8+ T cells are generated by skin immunization with live virus vectored micronee-dle arrays. $J$. Control. Release 2017, 268, 166-175. [CrossRef]

28. Qiu, Y.; Guo, L.; Zhang, S.; Xu, B.; Gao, Y.; Hu, Y.; Hou, J.; Bai, B.; Shen, H.; Mao, P. DNA-based vaccination against hepatitis B virus using dissolving microneedle arrays adjuvanted by cationic liposomes and CpG ODN. Drug Deliv. 2016, 23, 2391-2398. [CrossRef]

29. Zhu, Z.; Ye, X.; Ku, Z.; Liu, Q.; Shen, C.; Luo, H.; Luan, H.; Zhang, C.; Tian, S.; Lim, C.; et al. Transcutaneous immunization via rapidly dissolvable microneedles protects against hand-foot-and-mouth disease caused by enterovirus 71 . J. Control. Release 2016, 243, 291-302. [CrossRef] [PubMed]

30. Nakatsukasa, A.; Kuruma, K.; Okamatsu, M.; Hiono, T.; Suzuki, M.; Matsuno, K.; Kida, H.; Oyamada, T.; Sakoda, Y. Potency of whole virus particle and split virion vaccines using dissolving microneedle against challenges of H1N1 and H5N1 in-fluenza viruses in mice. Vaccine 2017, 35, 2855-2861. [CrossRef] [PubMed]

31. Chu, L.Y.; Prausnitz, M.R. Separable arrowhead microneedles. J. Control. Release 2011, 149, 242-249. [CrossRef] [PubMed]

32. Chu, L.Y.; Ye, L.; Dong, K.; Compans, R.W.; Yang, C.; Prausnitz, M.R. Enhanced stability of inactivated influenza vaccine en-capsulated in dissolving microneedle patches. Pharm. Res. 2016, 33, 868-878. [CrossRef]

33. Raphael, A.P.; Prow, T.W.; Crichton, M.L.; Chen, X.; Fernando, G.J.; Kendall, M.A. Targeted, needle-free vaccinations in skin us-ing multilayered, densely-packed dissolving microprojection arrays. Small 2010, 6, 1785-1793. [CrossRef]

34. Kuwentrai, C.; Yu, J.; Rong, L.; Zhang, B.Z.; Hu, Y.F.; Gong, H.R.; Dou, Y.; Deng, J.; Huang, J.D.; Xu, C. Intradermal delivery of re-ceptor-binding domain of SARS-CoV-2 spike protein with dissolvable microneedles to induce humoral and cellular responses in mice. Bioeng. Transl. Med. 2020, 6, e10202.

35. Liao, J.F.; Lee, J.C.; Lin, C.K.; Wei, K.C.; Chen, P.Y.; Yang, H.W. Self-assembly DNA polyplex vaccine inside dissolving microneedles for high-potency intradermal vaccination. Theranostics 2017, 7, 2593. [CrossRef]

36. Poirier, D.; Renaud, F.; Dewar, V.; Strodiot, L.; Wauters, F.; Janimak, J.; Shimada, T.; Nomura, T.; Kabata, K.; Kuruma, K.; et al. Hepatitis B surface antigen incorporated in dissolvable microneedle array patch is antigenic and thermostable. Biomaterials 2017, 145, 256-265. [CrossRef]

37. Cuevas, M.B.; Kodani, M.; Choi, Y.; Joyce, J.; O'connor, S.M.; Kamili, S.; Prausnitz, M.R. Hepatitis B vaccination using a dissolvable microneedle patch is immunogenic in mice and rhesus macaques. Bioeng. Transl. Med. 2018, 3, 186-196. [CrossRef]

38. Wang, T.; Zhen, Y.; Ma, X.; Wei, B.; Li, S.; Wang, N. Mannosylated and lipid A-incorporating cationic liposomes constituting microneedle arrays as an effective oral mucosal HBV vaccine applicable in the controlled temperature chain. Colloids Surfaces $B$ Biointerfaces 2015, 126, 520-530. [CrossRef]

39. Edens, C.; Collins, M.L.; Goodson, J.L.; Rota, P.A.; Prausnitz, M.R. A microneedle patch containing measles vaccine is immunogenic in non-human primates. Vaccine 2015, 33, 4712-4718. [CrossRef] 
40. Joyce, J.C.; Carroll, T.D.; Collins, M.L.; Chen, M.H.; Fritts, L.; Dutra, J.C.; Rourke, T.L.; Goodson, J.L.; McChesney, M.B.; Prausnitz, M.R.; et al. A microneedle patch for measles and rubella vaccination is immunogenic and protective in infant rhesus ma-caques. J. Infect. Dis. 2018, 218, 124-132. [CrossRef]

41. Kim, E.; Erdos, G.; Huang, S.; Kenniston, T.; Falo, L.D., Jr.; Gambotto, A. Preventative vaccines for Zika virus outbreak: Prelim-inary evaluation. EBioMedicine 2016, 13, 315-320. [CrossRef] [PubMed]

42. Arya, J.M.; Dewitt, K.; Scott-Garrard, M.; Chiang, Y.W.; Prausnitz, M.R. Rabies vaccination in dogs using a dissolving mi-croneedle patch. J. Control. Release 2016, 239, 19-26. [CrossRef] [PubMed]

43. Pattani, A.; McKay, P.F.; Garland, M.J.; Curran, R.M.; Migalska, K.; Cassidy, C.M.; Malcolm, R.K.; Shattock, R.J.; McCarthy, H.O.; Donnelly, R.F. Microneedle mediated intradermal delivery of adjuvanted recombinant HIV-1 CN54gp140 effectively primes mucosal boost inoculations. J. Control. Release 2012, 162, 529-537. [CrossRef] [PubMed]

44. Yan, Q.; Liu, H.; Cheng, Z.; Xue, Y.; Cheng, Z.; Dai, X.; Shan, W.; Chen, F. Immunotherapeutic effect of BCG-polysaccharide nu-cleic acid powder on Mycobacterium tuberculosis-infected mice using microneedle patches. Drug Deliv. 2017, 24, 1648-1653. [CrossRef] [PubMed]

45. Cole, G.; Ali, A.A.; McCrudden, C.M.; McBride, J.W.; McCaffrey, J.; Robson, T.; Kett, V.L.; Dunne, N.J.; Donnelly, R.F.; McCarthy, H.O. DNA vaccination for cervical cancer: Strategic optimisation of RALA mediated gene delivery from a biodegradable microneedle system. Eur. J. Pharm. Biopharm. 2018, 127, 288-297. [CrossRef]

46. Ali, A.A.; McCrudden, C.M.; McCaffrey, J.; McBride, J.W.; Cole, G.; Dunne, N.J.; Robson, T.; Kissenpfennig, A.; Donnelly, R.F.; McCarthy, H.O. DNA vaccination for cervical cancer; a novel technology platform of RALA mediated gene delivery via polymeric microneedles. Nanomed. Nanotechnol. Biol. Med. 2017, 13, 921-932. [CrossRef]

47. Wang, N.; Zhen, Y.; Jin, Y.; Wang, X.; Li, N.; Jiang, S.; Wang, T. Combining different types of multifunctional liposomes loaded with ammonium bicarbonate to fabricate microneedle arrays as a vaginal mucosal vaccine adjuvant-dual delivery sys-tem (VADDS). $J$. Control. Release 2017, 246, 12-29. [CrossRef] [PubMed]

48. Gala, R.P.; Zaman, R.U.; D'Souza, M.J.; Zughaier, S.M. Novel Whole-Cell Inactivated Neisseria Gonorrhoeae Microparticles as Vaccine Formulation in Microneedle-Based Transdermal Immunization. Vaccines 2018, 6, 60. [CrossRef] [PubMed]

49. Donadei, A.; Kraan, H.; Ophorst, O.; Flynn, O.; O’Mahony, C.; Soema, P.C.; Moore, A.C. Skin delivery of trivalent Sabin inactivated poliovirus vaccine using dissolvable microneedle patches induces neutralizing antibodies. J. Control. Release 2019, 311, 96-103. [CrossRef]

50. Edens, C.; Dybdahl-Sissoko, N.C.; Weldon, W.C.; Oberste, M.S.; Prausnitz, M.R. Inactivated polio vaccination using a mi-croneedle patch is immunogenic in the rhesus macaque. Vaccine 2015, 33, 4683-4690. [CrossRef]

51. Kolluru, C.; Gomaa, Y.; Prausnitz, M.R. Development of a thermostable microneedle patch for polio vaccination. Drug Deliv. Transl. Res. 2019, 9, 192-203. [CrossRef]

52. Vassilieva, E.V.; Kalluri, H.; McAllister, D.; Taherbhai, M.T.; Esser, E.S.; Pewin, W.P.; Pulit-Penaloza, J.A.; Prausnitz, M.R.; Compans, R.W.; Skountzou, I. Improved immunogenicity of individual influenza vaccine components delivered with a novel dis-solving microneedle patch stable at room temperature. Drug Deliv. Transl. Res. 2015, 5, 360-371. [CrossRef] [PubMed]

53. Kommareddy, S.; Baudner, B.C.; Oh, S.; Kwon, S.-Y.; Singh, M.; O’Hagan, D.T. Dissolvable Microneedle Patches for the Delivery of Cell-Culture-Derived Influenza Vaccine Antigens. J. Pharm. Sci. 2012, 101, 1021-1027. [CrossRef]

54. Allen, E.A.; O’Mahony, C.; Cronin, M.; O’Mahony, T.; Moore, A.C.; Crean, A.M. Dissolvable microneedle fabrication using pi-ezoelectric dispensing technology. Int. J. Pharm. 2016, 500, 1-10. [CrossRef]

55. Mistilis, M.J.; Bommarius, A.S.; Prausnitz, M.R. Development of a thermostable microneedle patch for influenza vaccina-tion. J. Pharm. Sci. 2015, 104, 740-749. [CrossRef]

56. Wang, J.; Li, B.; Wu, M.X. Effective and lesion-free cutaneous influenza vaccination. Proc. Natl. Acad. Sci. USA 2015, 112, 5005-5010. [CrossRef] [PubMed]

57. Mistilis, M.J.; Joyce, J.C.; Esser, E.S.; Skountzou, I.; Compans, R.W.; Bommarius, A.S.; Prausnitz, M.R. Long-term stability of influ-enza vaccine in a dissolving microneedle patch. Drug Deliv. Transl. Res. 2017, 7, 195-205. [CrossRef]

58. Vassilieva, E.V.; Wang, S.; Li, S.; Prausnitz, M.R.; Compans, R.W. Skin immunization by microneedle patch overcomes statininduced suppression of immune responses to influenza vaccine. Sci. Rep. 2017, 7, 17855. [CrossRef]

59. Littauer, E.Q.; Mills, L.K.; Brock, N.; Esser, E.S.; Romanyuk, A.; Pulit-Penaloza, J.A.; Vassilieva, E.V.; Beaver, J.T.; Antao, O.; Krammer, F; et al. Stable incorporation of GM-CSF into dissolvable microneedle patch improves skin vaccination against influenza. J. Control. Release 2018, 276, 1-16. [CrossRef] [PubMed]

60. Esser, E.S.; Pulit-Penaloza, J.A.; Kalluri, H.; McAllister, D.; Vassilieva, E.V.; Littauer, E.Q.; Lelutiu, N.; Prausnitz, M.R.; Compans, R.W.; Skountzou, I. Microneedle patch delivery of influenza vaccine during pregnancy enhances maternal immune re-sponses promoting survival and long-lasting passive immunity to offspring. Sci. Rep. 2017, 7, 1-11. [CrossRef]

61. Hirobe, S.; Azukizawa, H.; Hanafusa, T.; Matsuo, K.; Quan, Y.-S.; Kamiyama, F.; Katayama, I.; Okada, N.; Nakagawa, S. Clinical study and stability assessment of a novel transcutaneous influenza vaccination using a dissolving microneedle patch. Biomaterials 2015, 57, 50-58. [CrossRef] [PubMed]

62. Zhu, W.; Pewin, W.; Wang, C.; Luo, Y.; Gonzalez, G.X.; Mohan, T.; Prausnitz, M.R.; Wang, B.-Z. A boosting skin vaccination with dissolving microneedle patch encapsulating M2e vaccine broadens the protective efficacy of conventional influenza vaccines. J. Control. Release 2017, 261, 1-9. [CrossRef] 
63. Deng, L.; Chang, T.Z.; Wang, Y.; Li, S.; Wang, S.; Matsuyama, S.; Yu, G.; Compans, R.W.; Li, J.D.; Prausnitz, M.R.; et al. Heterosubtypic influenza protection elicited by double-layered polypeptide nanoparticles in mice. Proc. Natl. Acad. Sci. USA 2018, 115, E7758-E7767. [CrossRef]

64. Zhu, W.; Li, S.; Wang, C.; Yu, G.; Prausnitz, M.R.; Wang, B.-Z. Enhanced Immune Responses Conferring Cross-Protection by Skin Vaccination With a Tri-Component Influenza Vaccine Using a Microneedle Patch. Front. Immunol 2018, 9, 1705. [CrossRef]

65. Rodgers, A.M.; McCrudden, M.T.; Vincente-Perez, E.M.; Dubois, A.V.; Ingram, R.J.; Larrañeta, E.; Kissenpfennig, A.; Donnelly, R.F. Design and characterisation of a dissolving microneedle patch for intradermal vaccination with heat-inactivated bacte-ria: A proof of concept study. Int. J. Pharm. 2018, 549, 87-95. [CrossRef]

66. Lanza, J.S.; Vucen, S.; Flynn, O.; Donadei, A.; Cojean, S.; Loiseau, P.M.; Fernandes, A.P.S.; Frézard, F.; Moore, A.C. A TLR9adjuvanted vaccine formulated into dissolvable microneedle patches or cationic liposomes protects against leishmaniasis after skin or subcutaneous immunization. Int. J. Pharm 2020, 586, 119390. [CrossRef] [PubMed]

67. Resch, T.K.; Wang, Y.; Moon, S.S.; Joyce, J.; Li, S.; Prausnitz, M.; Jiang, B. Inactivated rotavirus vaccine by parenteral administra-tion induces mucosal immunity in mice. Sci. Rep. 2018, 8, 1-11. [CrossRef] [PubMed]

68. Kim, E.; Erdos, G.; Huang, S.; Kenniston, T.W.; Balmert, S.C.; Carey, C.D.; Raj, V.S.; Epperly, M.W.; Klimstra, W.B.; Haagmans, B.L.; et al. Microneedle array delivered recombinant coronavirus vaccines: Immunogenicity and rapid translational development. EBioMedicine 2020, 55, 102743. [CrossRef]

69. Hsueh, K.J.; Chen, M.C.; Cheng, L.T.; Lee, J.W.; Chung, W.B.; Chu, C.Y. Transcutaneous immunization of Streptococcus suis bac-terin using dissolving microneedles. Comp. Immunol. Microbiol. Infect. Dis. 2017, 50, 78-87. [CrossRef]

70. Liu, S.; Zhang, S.; Duan, Y.; Niu, Y.; Gu, H.; Zhao, Z.; Zhang, S.; Yang, Y.; Wang, X.; Gao, Y.; et al. Transcutaneous immunization of recombinant Staphylococcal enterotoxin B protein using a dissolving microneedle provides potent protection against lethal enterotoxin challenge. Vaccine 2019, 37, 3810-3819. [CrossRef] [PubMed]

71. Chen, F.; Yan, Q.; Yu, Y.; Wu, M.X. BCG vaccine powder-laden and dissolvable microneedle arrays for lesion-free vaccina-tion. J. Control. Release 2017, 255, 36-44. [CrossRef]

72. Lee, C.; Kim, H.; Kim, S.; Lahiji, S.F.; Ha, N.-Y.; Yang, H.; Kang, G.; Nguyen, H.Y.T.; Kim, Y.; Choi, M.-S.; et al. Comparative Study of Two Droplet-Based Dissolving Microneedle Fabrication Methods for Skin Vaccination. Adv. Healthc. Mater. 2018, 7, e1701381. [CrossRef]

73. Esser, E.S.; Romanyuk, A.; Vassilieva, E.V.; Jacob, J.; Prausnitz, M.R.; Compans, R.W.; Skountzou, I. Tetanus vaccination with a dissolving microneedle patch confers protective immune responses in pregnancy. J. Control. Release 2016, 236, 47-56. [CrossRef] [PubMed]

74. Hirobe, S.; Azukizawa, H.; Matsuo, K.; Zhai, Y.; Quan, Y.S.; Kamiyama, F.; Suzuki, H.; Katayama, I.; Okada, N.; Nakagawa, S. De-velopment and clinical study of a self-dissolving microneedle patch for transcutaneous immunization device. Pharm. Res. 2013, 30, 2664-2674. [CrossRef]

75. Yan, Q.; Cheng, Z.; Liu, H.; Shan, W.; Cheng, Z.; Dai, X.; Xue, Y.; Chen, F. Enhancement of Ag85B DNA vaccine immunogenicity against tuberculosis by dissolving microneedles in mice. Vaccine 2018, 36, 4471-4476. [CrossRef]

76. Arya, J.; Henry, S.; Kalluri, H.; McAllister, D.V.; Pewin, W.P.; Prausnitz, M.R. Tolerability, usability and acceptability of dis-solving microneedle patch administration in human subjects. Biomaterials 2017, 128, 1-7. [CrossRef]

77. De Perio, M.A. Needlestick injuries among employees at a retail pharmacy chain-nationwide. In Health Hazard Evaluation Report 2011-0063-3154 Needlestick Injuries among Employees at retail Pharmacy Chain-Nationwide; Centers for Dis-ease Control and Prevention: Atlanta, GA, USA, 2012.

78. PrüssÜstün, A.; Rapiti, E.; Hutin, Y.J. Sharps Injuries: Global Burden of Disease from Sharps Injuries to Health-Care Workers; WHO: Geneva, Switzerland, 2003.

79. Quinn, H.L.; Kearney, M.-C.; Courtenay, A.J.; McCrudden, M.T.C.; Donnelly, R.F. The role of microneedles for drug and vaccine delivery. Expert Opin. Drug Deliv. 2014, 11, 1769-1780. [CrossRef] [PubMed]

80. Li, J.; Zeng, M.; Shan, H.; Tong, C. Microneedle Patches as Drug and Vaccine Delivery Platform. Curr. Med. Chem. 2017, 24, 2413-2422. [CrossRef] [PubMed]

81. Prausnitz, M.R. Engineering Microneedle Patches for Vaccination and Drug Delivery to Skin. Annu. Rev. Chem. Biomol. Eng. 2017, 8, 177-200. [CrossRef] [PubMed]

82. Alliance, T.W.B.G. Immunization Financing Toolkit: A Resource for Policy-Makers and Program Managers; WHO: Geneva, Switzerland, 2010.

83. Lee, B.Y.; Bartsch, S.M.; Mvundura, M.; Jarrahian, C.; Zapf, K.M.; Marinan, K.; Wateska, A.R.; Snyder, B.; Swaminathan, S.; Jacoby, E.; et al. An economic model assessing the value of microneedle patch delivery of the seasonal influenza vaccine. Vaccine 2015, 33, 4727-4736. [CrossRef] [PubMed]

84. Norman, J.J.; Arya, J.M.; McClain, M.A.; Frew, P.M.; Meltzer, M.I.; Prausnitz, M.R. Microneedle patches: Usability and acceptability for self-vaccination against influenza. Vaccine 2014, 32, 1856-1862. [CrossRef]

85. BARDA's Rapidly Expanding COVID-19 Medical Countermeasure Portfolio. Available online: https://www.medicalcountermeasures. gov/app/barda/coronavirus/COVID19.aspx (accessed on 29 January 2021). 